\title{
DESIGN AND DEVELOPMENT OF A LOW COST MOUNTED \\ TYPE SINGLE LEG SUBSOILER
}

\section{P L A G Alwis, K H D Abeyrathna, LW S Pemasiri and P Pallyaguru \\ Faculty of Agriculture, \\ University of Ruhuna}

Free movement of air in the soil and good drainage are necessary for good crop yields. Modern tractors and machinery are partly responsible for soil compaction and soil pans. Subsoilers are used to break compacted soil, allowing free passage of air and water. For conducting this important operation in crop production, suitable Subsoiler does not exist in Sri Lanka. However without proper land preparation, higher yield of crop production by applying other input cannot be expected. Therefore fields should be subsoiled time to time at right angles to the intended direction of ploughing. Sometimes farmers use expensive, un tested, imported Ploughs for this purpose. The commercial ploughs used in many developed countries, are beyond the financial capabilities of local paddy farmers. Properly designed subsoilers are usually mounted on the tractor and consist of a strong frame with one or more legs. Each leg has a replaceable point. Working depth is normally from 30 to $50 \mathrm{~cm}$ and spacing between passes is from 0.5 to $2 \mathrm{~m}$. Subsoiling is best carried out after the cereal harvest when the soil is dry.

Considering the above facts, a low cost suitable Subsoiler for four wheel tractors was designed and constructed after testing first model Subsoiler in the field and implementing necessary modifications.

An experiment was conducied in the paddy field to compare the performances of the developed Subsoiler. The result shows that the effective field capacity, effective working 
width, ploughing depth, travel reduction, average operation speed, and Cost of production of Subsoiler were $0.2 \mathrm{ha} / \mathrm{hr}, 0.5 \mathrm{~m}, 0.3 \mathrm{~m}, 6 \%, 1.6 \mathrm{~km} / \mathrm{hr}, 5000 \mathrm{Rs}$ respectively. The result shows that the overall field performances of designed Subsoiler was satisfactory.

Proceedings of the Ninth Annual Forestry and Environment Symposium 2003 of the Department of Forestry and Environmental Science, University of Sri Jayewandenepura, Sri Lanka 